\title{
Rubrobacter xylanophilus sp. nov., a New Thermophilic Species Isolated from a Thermally Polluted Effluent
}

\author{
LAURA CARRETO, ${ }^{1}$ EDWARD MOORE, ${ }^{2}$ M. FERNANDA NOBRE, ${ }^{3}$ ROBIN WAIT, ${ }^{4}$ \\ PAUL W. RILEY, ${ }^{4}$ RICHARD J. SHARP,${ }^{4}$ AND MILTON S. DA COSTA ${ }^{1 *}$ \\ Departamento de Bioquímica, ${ }^{1}$ and Departamento de Zoologia, ${ }^{3}$ Universidade de Coimbra, \\ 3000 Coimbra, Portugal; Bereich Mikrobiologie, Gesellschaft für Biotechnologische Forschung, \\ 38124 Braunschweig, Germany ${ }^{2}$; and Centre for Applied Microbiology and Research, \\ Porton Down, Salisbury, Wiltshire SP4 OJG, United Kingdom ${ }^{4}$
}

\begin{abstract}
One strain of a thermophilic, slightly halotolerant bacterium was isolated from a thermally polluted industrial runoff near Salisbury, United Kingdom. This organism, strain PRD-1 ${ }^{T}$ ( $T=$ type strain), for which we propose the name Rubrobacter xylanophilus sp. nov., produces short gram-positive rods and coccoid cells and forms pink colonies. The optimum growth temperature is approximately $60^{\circ} \mathrm{C}$. Unusual internal branchedchain fatty acids (namely, 12-methylhexadecanoic acid and 14-methyloctadecanoic acid) make up the major acyl chains of the lipids. The results of our $16 \mathrm{~S}$ rRNA sequence comparisons showed that strain PRD-1 ${ }^{\mathrm{T}}$ is related to Rubrobacter radiotolerans and that these two organisms form a deep evolutionary line of descent within the gram-positive Bacteria.
\end{abstract}

Over the past 20 years the microbiology of thermophiles has been dominated by the isolation and characterization of thermophilic Archaea species, many of which grow at extreme temperatures. During this time, however, many new thermophilic Bacteria species, several belonging to the gram-positive phylum, have been isolated from a wide range of thermal environments. The majority of the thermophilic gram-positive Bacteria species that have been described belong to the genera Bacillus, Alicyclobacillus, and Clostridium and other recently proposed genera, some of which were formerly included in the genus Clostridium $(3,5,18,28,33,40)$.

The species Rubrobacter radiotolerans, which was initially named Arthrobacter radiotolerans, was described on the basis of one strain isolated from a hot spring in Japan after gamma irradiation of water samples $(35,44)$. $R$. radiotolerans is gram positive, has an optimum growth temperature of about $48^{\circ} \mathrm{C}$, and forms short pleomorphic rod-shaped cells. It is also highly radiotolerant and possesses unique internally branched fatty acids.

A pink-pigmented strain was recently isolated from a thermally polluted runoff from a carpet factory in the United Kingdom. This organism is more thermophilic than $R$. radiotolerans and also possesses unusual branched-chain fatty acids. On the basis of morphological and biochemical characteristics, chemotaxonomic parameters, and 16S rRNA gene sequence data, we propose that this organism, strain PRD $-1^{\mathrm{T}}(\mathrm{T}=$ type strain $)$, belongs to a new species, Rubrobacter xylanophilus.

\section{MATERIALS AND METHODS}

Isolation of strain PRD-1 ${ }^{T}$. Strain PRD-1 ${ }^{\mathrm{T}}$ was isolated from thermally polluted runoff (temperature, $50^{\circ} \mathrm{C}$ ) from a carpet factory in Wilton, Wiltshire, United Kingdom. This strain was isolated by spreading a biofilm sample with a glass rod on tryptone soya agar. After incubation at $50^{\circ} \mathrm{C}$ for 5 days, one pinkpigmented colony appeared on a culture plate and was purified on the same medium. $R$. radiotolerans DSM $46359^{\mathrm{T}}$ was obtained from the Deutsche Sammlung von Mikroorganismen und Zellkulturen, Braunschweig, Germany. Strains PRD-1 ${ }^{\mathrm{T}}$ and DSM $46359^{\mathrm{T}}$ were routinely grown in Thermus medium containing $1.0 \mathrm{~g}$ of yeast extract per liter and $1.0 \mathrm{~g}$ of tryptone medium (41) per liter and were stored at $-80^{\circ} \mathrm{C}$ in the same medium containing $15 \%$ glycerol.

* Corresponding author. Phone: 351-39-29802. Fax: 351-39-26798. Electronic mail address: Milton@gemini.ci.uc.pt.
Corynebacterium xerosis ATCC $373^{\mathrm{T}}$, which was obtained from the American Type Culture Collection, Rockville, Md., Corynebacterium sp. strain DSM 20146, and Mycobacterium smegmatis ATCC $19420^{\mathrm{T}}$ were used as reference strains during extraction and chromatographic separation of mycolic acids. These organisms were grown in the appropriate growth media as described in the DSM Catalogue of Strains (6).

Morphological and biochemical characteristics. Cell morphology and motility were examined by phase-contrast microscopy during the exponential growth phase in Thermus medium. Unless indicated otherwise, biochemical and tolerance tests were performed as described by Santos et al. (31) and Manaia and da Costa (19) at $45^{\circ} \mathrm{C}$ for $R$. radiotolerans and at $60^{\circ} \mathrm{C}$ for strain PRD-1 $1^{\mathrm{T}}$ for up to 5 days. The temperature ranges for growth of $R$. radiotolerans and strain PRD-1 ${ }^{\mathrm{T}}$ were determined by incubating the organisms at temperatures between 35 and $75^{\circ} \mathrm{C}$ in $300-\mathrm{ml}$ metal-capped Erlenmeyer flasks containing $100 \mathrm{ml}$ of Thermus medium in a reciprocal water bath shaker. The $\mathrm{pH}$ range for growth of strain PRD- $1^{\mathrm{T}}$ was determined in Thermus medium buffered at $\mathrm{pH} 6.0$ and 6.5 with 20 $\mathrm{mM}$ MES [2-( $N$-morpholino)ethanesulfonic acid], at pH 7.0 to 8.5 with $20 \mathrm{mM}$ HEPES ( $N$-2-hydroxyethylpiperazine- $N^{\prime}$-2-ethanesulfonic acid), and at $\mathrm{pH} 9.0$, 9.5 , and 10.0 with $20 \mathrm{mM}$ CAPSO [3-(cyclohexylamino)-2-hydroxy-1-propanesulfonic acid].

Single-carbon-source assimilation experiments were performed by using a minimal medium composed of CMD (2) basal salts medium to which filtersterilized carbon sources $\left(2.0 \mathrm{~g} \mathrm{liter}^{-1}\right)$, yeast extract $\left(0.2 \mathrm{~g} \mathrm{liter}^{-1}\right)$, and ammonium sulfate $\left(0.5 \mathrm{~g} \mathrm{liter}^{-1}\right)$ were added. Growth was examined turbidimetrically at $610 \mathrm{~nm}$ after growth for 7 days in metal-capped tubes (16 by $160 \mathrm{~mm}$ ) containing $5.0 \mathrm{ml}$ of medium incubated at $60^{\circ} \mathrm{C}$ in a water bath. The negative controls contained no carbon source; growth was also monitored in Thermus medium.

Determination of the $\mathbf{G}+\mathbf{C}$ content of DNA. Cells from a $500-\mathrm{ml}$ overnight culture were harvested by centrifugation and resuspended in $10 \mathrm{ml}$ of $50 \mathrm{mM}$ Tris- $\mathrm{HCl}(\mathrm{pH} 8.0)$. Then lysozyme $(10 \mathrm{mg})$ was added, and the cell suspension was incubated for $45 \mathrm{~min}$ at $4^{\circ} \mathrm{C}$. Proteinase $\mathrm{K}$ and sodium dodecyl sulfate were added to final concentrations of $1 \mathrm{mg} \mathrm{m}^{-1}$ and $0.2 \%$, respectively, and the mixture was kept on ice for an additional $2 \mathrm{~h}$. The proteins were denatured by adding an equal volume of $2 \mathrm{M}$ sodium perchlorate and then an equal volume of chloroform and gently mixing the preparation until a stable emulsion was obtained. The suspension was centrifuged at $12,000 \times \mathrm{g}$ for $5 \mathrm{~min}$ at $4^{\circ} \mathrm{C}$, and the aqueous layer was recovered. After 2 volumes of ice-cold ethanol was added, the DNA was spooled, dried in a stream of air, and dissolved in $5 \mathrm{ml}$ of TE buffer (10 $\mathrm{mM}$ Tris- $\mathrm{HCl}, 1.0 \mathrm{mM}$ EDTA; $\mathrm{pH} 8.0)$. DNase-free RNase $(1.0 \mathrm{mg})$ was added, and the mixture was incubated overnight at $4^{\circ} \mathrm{C}$. An equal volume of phenol was added, and the suspension was mixed gently. The resulting mixture was centrifuged at $5,000 \times g$ for $5 \mathrm{~min}$ at $4^{\circ} \mathrm{C}$, and the top layer was recovered. The remaining phenol was removed by washing the preparation three times with ether. The DNA was spooled as described above and resuspended in $0.1 \times \mathrm{SSC}$ ( $1 \times \mathrm{SSC}$ is $0.015 \mathrm{M}$ trisodium citrate plus $0.15 \mathrm{M} \mathrm{NaCl}$ ).

The DNA base composition was determined by the thermal denaturation method of Marmur and Doty (20) in $0.1 \times$ SSC by using a Pye Unicam SP-100 spectrophotometer equipped with a temperature program controller. The $\mathrm{G}+\mathrm{C}$ content was determined from the denaturation temperature by the method of Gillis et al. (9). The denaturation temperature of Escherichia coli B (= ATCC 
23226 ) in $0.1 \times \mathrm{SSC}$ was determined to be $73.2^{\circ} \mathrm{C}$. Other $\mathrm{G}+\mathrm{C}$ contents were derived from this value.

Genomic DNA isolation, PCR amplification and determination of the $16 \mathrm{~S}$ ribosomal DNA sequence. Genomic DNA was isolated by the $\mathrm{CTAB}$ (hexadecyl trimethylammonium bromide) method of Wilson (42). Nearly complete $16 \mathrm{~S}$ rRNA genes were amplified by PCR $(22,30)$ by using forward primer $16 \mathrm{~F} 27$ (5'-AGAGTTTGATCMTGGCTCAG-3' [M = A or C]; hybridizing at positions 8 to 27 [E. coli $16 \mathrm{~S}$ rRNA gene sequence numbering]) and reverse primer 16R1525 (5'-AAGGAGGTGWTCCAGCC-3' [W = A or T]; hybridizing at the complement of positions 1525 to 1541). PCR amplification was performed by using a GeneAmp 9600 apparatus (Perkin-EImer Corp., Norwalk, Conn.) and the reaction conditions described previously (14).

PCR DNA products were purified by using Centricon-100 microconcentrators (Amicon GmbH, Witten, Germany). The purified PCR DNA was sequenced directly by using an Applied Biosystems model 373A DNA sequencer, the protocol recommended by the manufacturer (Perkin-Elmer Applied Biosystems Gmb, Weiterstadt, Germany) for Taq cycle sequencing, and fluorescent-dyelabeled dideoxynucleotides. The sequences of both strands of the PCR-amplified $16 \mathrm{~S}$ ribosomal DNAs were determined by using the forward and reverse oligonucleotide primers described previously (17). The sequence data obtained were aligned with reference rRNA sequence data that were maintained in an in-house database by using the evolutionarily conserved primary sequence and secondary structure as references $(10,43)$. Evolutionary distances were calculated from masked sequence pair levels of similarity (17), and a correction factor for back mutations was included (13). We used a weighted, least-squares distance method (24) to generate dendrograms

Polar lipid, lipoquinone, mycolic acid, and peptidoglycan analyses and fatty acid composition. The cultures used for polar lipid analysis were grown in 1-liter Erlenmeyer flasks containing $200 \mathrm{ml}$ of Thermus medium at $45^{\circ} \mathrm{C}$ for $R$. radiotolerans and at $60^{\circ} \mathrm{C}$ for strain PRD $-1^{\mathrm{T}}$ in a reciprocal water bath shaker until the late exponential phase of growth. Harvesting of the cultures, extraction of the lipids, and two-dimensional thin-layer chromatography were performed as described previously $(7,27)$.

Lipoquinones were extracted from freeze-dried cells and were purified by thin-layer chromatography as described by Tindall (36). The lipoquinones were separated with a Gilson high-performance liquid chromatograph by using a reverse-phase (RP18) Spherisorb S5 ODS2 column and methanol-heptane (10:2, $\mathrm{vol} / \mathrm{vol}$ ) as the mobile phase and were detected at $269 \mathrm{~nm}$.

Mycolic acids were extracted from cells obtained from growth in the appropriate growth medium by using the method of Minnikin et al. (21). Thin-layer chromatography was performed on Silica Gel 60 plates $(10$ by $20 \mathrm{~cm}$; thickness, $0.25 \mathrm{~mm}$; Merck) by using triple development with petroleum ether (bp, 60 to $\left.80^{\circ} \mathrm{C}\right)$-acetone $(95: 5, \mathrm{vol} / \mathrm{vol})$. The components were revealed with molybdophosphoric acid.

Peptidoglycan was prepared and peptidoglycan structure was determined as described by Schleifer and Kandler (32). Freeze-dried cells (1 mg) were hydrolyzed in $0.2 \mathrm{ml}$ of $4 \mathrm{~N} \mathrm{HCl}$ at $100^{\circ} \mathrm{C}$ for $16 \mathrm{~h}$ (total hydrolysate) or for $45 \mathrm{~min}$ (partial hydrolysate). The diamino acid content was determined by one-dimensional thin-layer chromatography on cellulose plates by using methanol-pyridine-water-10 N HCl (32:4:7:1, vol/vol) solvent system. Amino acids and peptides were identified after two-dimensional thin-layer chromatography performed with the solvent systems of Schleifer and Kandler (32) by their mobilities and staining properties with ninhydrin.

For the fatty acid analysis $R$. radiotolerans was grown at 37 and $45^{\circ} \mathrm{C}$ and strain PRD- $1^{\mathrm{T}}$ was grown at 45 and $60^{\circ} \mathrm{C}$ until the mid-exponential phase of growth. Fatty acid methyl esters were obtained from fresh wet biomass by saponification, methylation, and extraction by using the method of Kuykendall et al. (16). Fatty acid methyl esters were separated with a Hewlett-Packard model 5890 gas chromatograph fitted with a $5 \%$ phenylmethyl silicone capillary column (Ultra 2;0.2 $\mathrm{mm}$ by $25 \mathrm{~m}$; Hewlett-Packard) by using the protocol of the Microbial Identification System (MIDI; Microbial ID, Inc., Newark, Del.). The fatty acid methyl esters were identified and quantified and a numerical analysis of the fatty acid profiles was performed by using the MIDI software package.

Mass spectrometry. Gas chromatography-mass spectrometry (GC-MS) was performed with a model MS80 RFA mass spectrometer (Kratos, Ltd., Manchester, United Kingdom) interfaced with a Carlo Erba model 5160 capillary gas chromatograph equipped with a type BPX-5 column $(0.2 \mathrm{~mm}$ by $25 \mathrm{~m}$; SGE Ltd., Milton Keynes, United Kingdom). Spectra were recorded by using electron ionization at an ionization energy of $70 \mathrm{eV}$, chemical ionization, and isobutane as the reagent gas. Negative ion fast atom bombardment mass spectra of isoprenoid quinones were obtained with the same instrument by using 3-nitrobenzyl alcohol as the liquid matrix. Samples were trimethylsilylated by treating them with $100 \mu \mathrm{l}$ of bis-(trimethylsilyl)-trifluoroacetamide (Fluka, Buchs, Switzerland) for $30 \mathrm{~min}$ at $60^{\circ} \mathrm{C}$. Picolinyl esters were prepared by the method of Harvey (12) as modified by Wait and Hudson (39).

Nucleic acid sequence accession numbers. The $16 \mathrm{~S}$ ribosomal DNA sequence data are available from EMBL under accession number X87134 for $R$. radiotolerans DSM $46359^{\mathrm{T}}$ and accession number X87135 for strain PRD-1 ${ }^{\mathrm{T}}$.

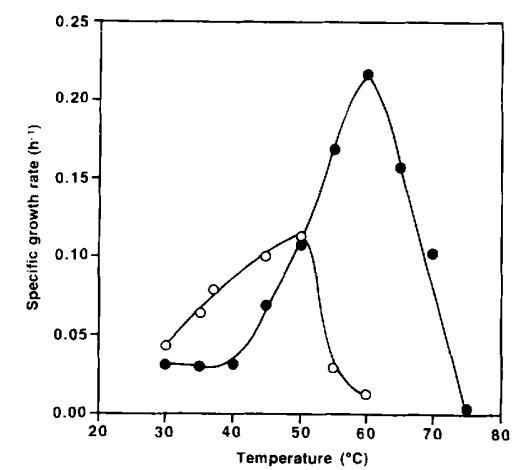

FIG. 1. Effect of temperature on the growth rates of $R$. radiotolerans $(O)$ and strain PRD $-1^{\Upsilon}(\mathbf{O})$.

\section{RESULTS AND DISCUSSION}

Morphological and biochemical characteristics. Strain PRD $-1^{T}$ produced very short, gram-positive, nonmotile, rodshaped cells and a few spherical cells in older cultures on solid medium. The colonies of strain PRD-1 $1^{\mathrm{T}}$ were light pink after growth at $60^{\circ} \mathrm{C}$, but bright pink after growth at $45^{\circ} \mathrm{C}$. The colonies of $R$. radiotolerans were bright pink.

The following media were tested initially to determine whether they supported growth of strain PRD-1 $1^{\mathrm{T}}$ and $R . r a$ diotolerans: nutrient broth, tryptic soy broth, medium 162 (4), and Thermus medium. Both organisms grew on all of the media, but growth was excellent on Thermus medium, and this medium was used throughout this study. Several biochemical characteristics, such as the presence of cytochrome oxidase and catalase, reduction of nitrate to nitrite, the inability to ferment carbohydrates, and the ability to grow in Thermus basal salts medium containing only $\left(\mathrm{NH}_{4}\right)_{2} \mathrm{SO}_{4}\left(0.5 \mathrm{~g} \mathrm{liter}^{-1}\right)$ and an appropriate carbon source, were identical in strain PRD-1 ${ }^{\mathrm{T}}$ and $R$. radiotolerans. The growth temperature range was the most outstanding differential characteristic for the two organisms (Fig. 1). Strain PRD-1 ${ }^{\mathrm{T}}$ had an optimum growth temperature of about $60^{\circ} \mathrm{C}$ and did not grow at temperatures above $70^{\circ} \mathrm{C}$, while $R$. radiotolerans had an optimum growth temperature between 45 and $50^{\circ} \mathrm{C}$ and did not grow at temperatures above $55^{\circ} \mathrm{C}$. Strain PRD $-1^{\mathrm{T}}$ hydrolyzed xylan, while $R$. radiotolerans did not. Several other phenotypic differences, including utilization of inositol by strain PRD-1 ${ }^{\mathrm{T}}$, distinguished strain PRD-1 ${ }^{\mathrm{T}}$ from $R$. radiotolerans (Table 1).

GC-MS. The fatty acid composition of strain PRD-1 ${ }^{T}$ was determined by gas chromatography, but several chromatographic peaks did not match the equivalent chain lengths of the fatty acid methyl esters in the MIDI database; we used GC-MS to identify these peaks. One peak eluted between 16:0 and 17:0 and had an electron ionization mass spectrum typical of a 17-carbon fatty acid (Table 2). The presence of a methyl branch at position 12 was indicated by three weak ions at $\mathrm{m} / \mathrm{z}$ 227 (cleavage distal to the methyl group, forming a stabilized carbocation), $m / z 195$ (loss of $\mathrm{CH}_{3} \mathrm{OH}$ from $\mathrm{m} / \mathrm{z} 227$ ), and $\mathrm{m} / \mathrm{z}$ 177 (loss of $\mathrm{H}_{2} \mathrm{O}$ from $\mathrm{m} / \mathrm{z}$ 195), which identified the compound as 12-methylhexadecanoic acid (12-methyl-16:0). Similar fragment ions were present in the mass spectrum of a minor peak that had a molecular ion at $m / z 298$, which was identified as 12- methylheptadecanoic acid (12-methyl-17:0). The equivalent chain length of the other component $\left(\mathrm{M}^{+}\right.$at $m / z$ 312) was less than 19:0, suggesting that the structure was branched. This compound was identified as 14-methyloctadecanoic acid (14methyl-18:0) by fragment ions at $m / z 255,223$, and 205 (29). A 
TABLE 1. Characteristics that distinguish $R$. radiotolerans from strain PRD-1 ${ }^{\mathrm{T} a}$

\begin{tabular}{|c|c|c|c|c|c|c|c|c|c|c|c|c|c|c|}
\hline \multirow[b]{2}{*}{ Organism } & \multirow{2}{*}{$\begin{array}{l}\text { Growth } \\
\text { at } 60^{\circ} \mathrm{C}\end{array}$} & \multirow{2}{*}{$\begin{array}{c}\text { Hydrolysis } \\
\text { of xylan }\end{array}$} & \multicolumn{12}{|c|}{ Utilization of the following carbon sources: } \\
\hline & & & $\begin{array}{c}\text { D-Galac- } \\
\text { tose }\end{array}$ & D-Xylose & $\begin{array}{l}\text { D-Meli- } \\
\text { biose }\end{array}$ & $\begin{array}{l}\text { Glyc- } \\
\text { erol }\end{array}$ & $\begin{array}{c}\text { Galac- } \\
\text { titol }\end{array}$ & $\begin{array}{l}\text { D-Manni- } \\
\text { tol }\end{array}$ & Ribitol & $\begin{array}{l}\text { myo-Inos- } \\
\text { itol }\end{array}$ & Acetate & $\begin{array}{c}\text { Succi- } \\
\text { nate }\end{array}$ & $\begin{array}{l}\text { L-Gluta- } \\
\text { mine }\end{array}$ & $\begin{array}{l}\text { Acet- } \\
\text { amide }\end{array}$ \\
\hline R. radiotolerans & $-{ }^{b}$ & - & - & - & - & + & - & + & + & - & - & - & - & - \\
\hline Strain PRD-1 ${ }^{\mathrm{T}}$ & + & + & + & + & + & - & $\mathrm{w}$ & - & - & + & w & + & w & + \\
\hline
\end{tabular}

${ }^{a}$ Both organisms grew in medium containing $6 \% \mathrm{NaCl}$; degraded hide powder azure, gelatin, hippurate, arbutin, and esculin; were cytocrome oxidase, catalase, and B-galactosidase positive; produced nitrite; and utilized D-glucose, D-mannose, D-fructose, L-arabinose, L-rhamnose, sucrose, D-trehalose, D-raffinose, lactose, Dcellobiose, erythritol, pyruvate, malate, L-glutamate, L-asparagine, L-proline, and salicin. Neither organism hydrolyzed elastin, fibrin, casein, starch, cellulose, tyrosine, olive oil, or Tween 80; degraded $p$-nitrophenyl- $\alpha$-glucopyranoside, $p$-nitrophenyl- $\beta$-glucopyranoside, $p$-nitrophenyl-laurate, or $p$-nitrophenyl-palmitate; had DNase or $\alpha$-galactosidase; or utilized D-sorbitol, citrate, and L-serine.

$b_{-}$, negative; + , positive; w, weakly positive.

small peak that eluted immediately before 14-methyl-18:0 was identified by GC-MS as 12-methyloctadecanoic acid (12-methyl-18:0).

The identities of the components described above were confirmed by the results of GC-MS of their picolinyl esters. In the mass spectrum of the picolinyl ester of 14-methyl-18:0 the low abundance of $\mathrm{m} / \mathrm{z} 318$ and the interval of 28 between $\mathrm{m} / \mathrm{z} 304$ and 332 confirmed the presence of a methyl group in position 14 (Fig. 2). The structure of 12-methyl-16:0 was also deduced from the mass spectrum of its picolinyl ester. The major fatty acid methyl esters of $R$. radiotolerans were identified by their mass spectra as 12-methyl-16:0 and 14-methyl-18:0.

The retention times of several unidentified peaks in the gas chromatograms increased after trimethylsilylation, indicating that hydroxyl groups were present. The results of an analysis in which electron ionization and chemical ionization GC-MS was used suggested that these peaks corresponded to long-chain primary alcohols containing 16, 17 (two isomers), 18, and 19 carbon atoms. Since the retention times of these compounds were somewhat less than those of the available straight-chain standards, their alkyl chains were probably branched. Mass spectrometry of the trimethylsilyl derivatives did not, however, result in full characterization of the alkyl chains.

Several late-eluting peaks detected in the gas chromatograms had mass spectra dominated by a fragment ion at $\mathrm{m} / \mathrm{z}$ 205 , which is known to be characteristic of $1-O$-alkyl-2,3-di- $O$ -

TABLE 2. Fatty acid and long-chain fatty alcohol compositions of $R$. radiotolerans and strain PRD-1 ${ }^{\mathrm{T}}$, at two growth temperatures

\begin{tabular}{|c|c|c|c|c|c|}
\hline \multirow{3}{*}{$\begin{array}{l}\text { Fatty acid or } \\
\text { fatty alcohol }\end{array}$} & \multirow{3}{*}{$\begin{array}{l}\text { Equivalent chain } \\
\text { length }\end{array}$} & \multicolumn{4}{|c|}{$\%$ of total in: } \\
\hline & & \multicolumn{2}{|c|}{$R$ radiotolerans } & \multicolumn{2}{|c|}{ Strain PRD-1 ${ }^{\mathrm{T}}$} \\
\hline & & $37^{\circ} \mathrm{C}$ & $45^{\circ} \mathrm{C}$ & $45^{\circ} \mathrm{C}$ & $60^{\circ} \mathrm{C}$ \\
\hline 16:0 alcohol & 15.549 & 14.5 & 4.5 & 1.3 & $\mathrm{ND}^{a}$ \\
\hline $16: 0$ & 16.000 & 4.5 & 6.6 & 5.3 & 2.3 \\
\hline 17:0 alcohol $^{b}$ & 16.080 & 8.7 & 4.7 & 4.8 & ND \\
\hline 12-methyl-16:0 & 16.504 & 38.3 & 54.1 & 9.8 & 12.4 \\
\hline Unknown 1 & 16.559 & ND & ND & 0.9 & ND \\
\hline Unknown 2 & 16.862 & ND & ND & 1.6 & 1.2 \\
\hline $17: 0$ & 17.000 & ND & ND & 0.9 & 1.2 \\
\hline Unknown 3 & 17.047 & ND & ND & 1.0 & ND \\
\hline 12-methyl-17:0 & 17.460 & ND & ND & 1.9 & 1.7 \\
\hline 18:0 alcohol & 17.577 & 17.7 & 10.5 & 8.9 & 2.2 \\
\hline $18: 0$ & 18.000 & 3.0 & 4.6 & 13.1 & 20.0 \\
\hline 19:0 alcohol & 18.099 & 5.1 & 3.9 & 8.2 & 2.3 \\
\hline 12-methyl-18:0 & 18.430 & ND & ND & 3.0 & 3.6 \\
\hline 14-methyl-18:0 & 18.512 & 8.3 & 11.2 & 37.1 & 53.0 \\
\hline $19: 0$ & 19.000 & ND & ND & 0.9 & ND \\
\hline
\end{tabular}

a ND, not detected.

${ }^{b}$ Two isomers were detected by GC-MS. trimethylsilyl glycerols (8). The results of chemical ionization GC-MS indicated that the two most abundant compounds were a pair of isomeric 1-heptadecyl-2,3-di- $O$-trimethylsilyl glycerols. In the absence of authentic standards, it was not possible to determine if the alkyl chains were branched from the mass spectra of the trimethylsilyl ether derivatives. A component with a mass spectrum very similar to the mass spectra of the $\mathrm{C}_{17}$ alkyl glycerols was also present in the spectrum of the $R$. radiotolerans extract.

Respiratory quinone, polar lipid, cell wall, mycolic acid, and fatty acid compositions. The only respiratory lipoquinone detected in strain PRD $-1^{\mathrm{T}}$ and $R$. radiotolerans was menaquinone 8 . The identity of the quinone was confirmed by negative ion fast ion bombardment mass spectrometry, which revealed a molecule that had a molecular anion at $m / z 716.7$, which is consistent with the presence of menaquinone 8 . Mycolic acids were not detected in either of the organisms.

The thin-layer chromatography polar lipid patterns of the two organisms were also similar and consisted of five phospholipids, including phosphatidylglycerol and diphosphatidylglycerol, one phosphoglycolipid, and one glycolipid (Fig. 3). These results are in agreement with the results of Suzuki et al. (35).

The peptidoglycan of strain PRD-1 $1^{\mathrm{T}}$ contained lysine, glutamic acid, and alanine at a molar ratio of 1:1:3. The results of an analysis of partial hydrolysates of the peptidoglycan were compatible with the identification of the peptidoglycan as type A3 $\alpha$ (L-Lys-L-Ala) as defined by Schleifer and Kandler (32), and the strain PRD- $1^{\mathrm{T}}$ peptidoglycan was identical to the peptidoglycan of $R$. radiotolerans (35).

The fatty acid compositions of strain PRD- ${ }^{\mathrm{T}}$ and $R$. $r a$ diotolerans were also qualitatively very similar. At the optimum growth temperature 14-methyl-18:0 was the major fatty acid in strain PRD- $1^{\mathrm{T}}$ (53\% of the total acyl groups), while 12-methyl$16: 0$ accounted for about $12 \%$ of the acyl groups; 12 -methyl17:0 and 12-methyl-18:0 were present in relatively minor amounts. In contrast to strain PRD-1 ${ }^{\mathrm{T}}, 12$-methyl-16:0 accounted for 54\% and 14-methyl-18:0 accounted for 11\% of the acyl chains in $R$. radiotolerans grown at $45^{\circ} \mathrm{C}$. The difference in the fatty acid compositions of the two organisms was not due to different growth temperatures since 14-methyl-18:0 was also the major fatty acid after growth of strain PRD- $1^{\mathrm{T}}$ at $45^{\circ} \mathrm{C}$ (Table 2). Several of the fatty acids identified in this study (namely, 12-methyl-17:0, 12-methyl-18:0, and 14-methyl-18:0) and the long-chain alcohols were not found previously in $R$. radiotolerans (35), and we did not detect anteiso-19:0 or 2-OH17:0.

Internally branched fatty acids with a methyl group at position 10 are common in mycolic acid-containing gram-positive bacteria $(1,15,34)$ and are present in some sulfate-reducing bacteria belonging to the Proteobacteria (37). In Thermomicrobium roseum 12-methyl-18:0 is the major fatty acid, and other internally branched fatty acids are also present (26), but this 

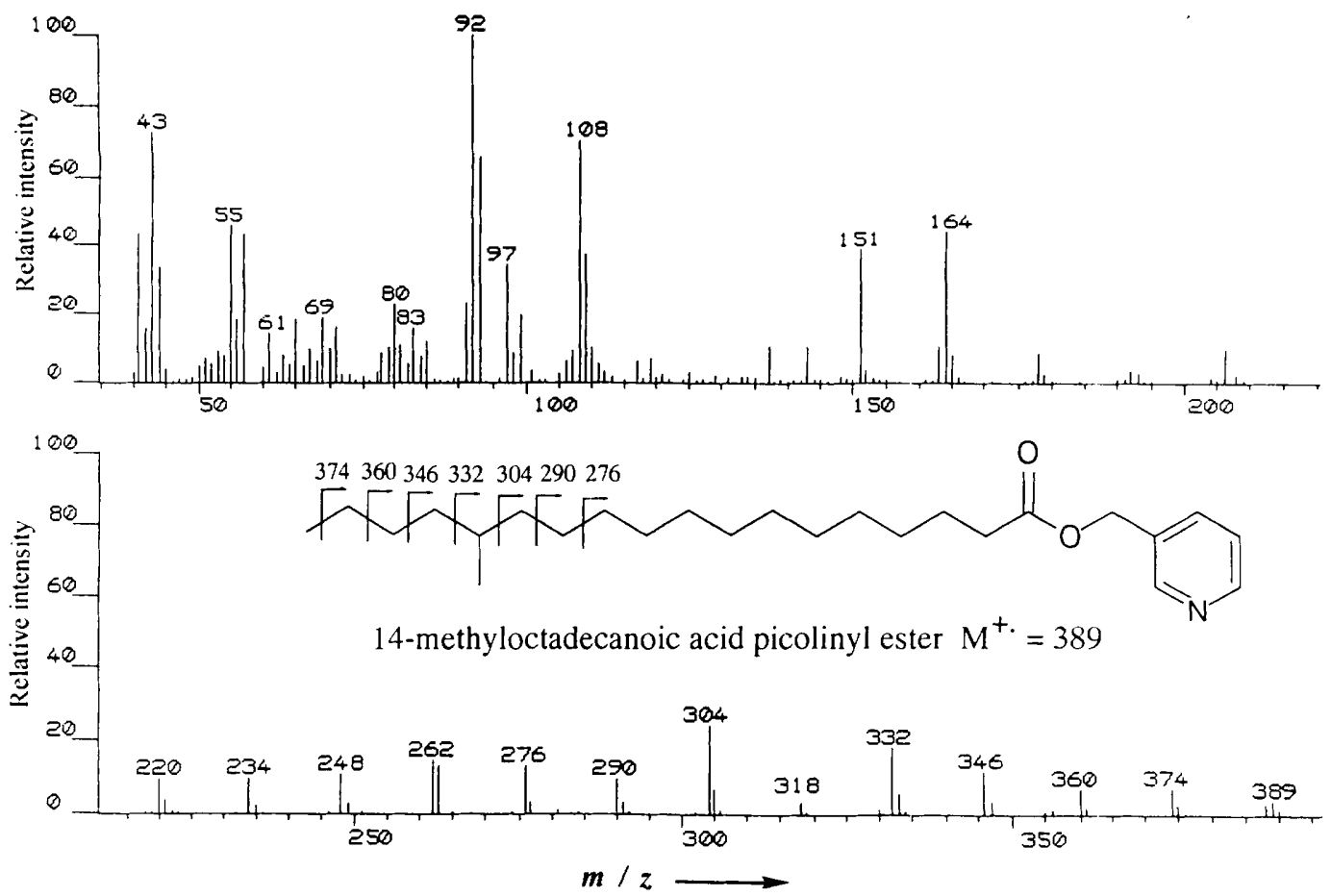

FIG. 2. Mass spectrum of the picolinyl ester derivative of 14-methyl-18:0 obtained from strain PRD-1 ${ }^{\mathrm{T}}$.

bacterium belongs to the green nonsulfur bacteria and is not related to $R$. radiotolerans and strain PRD $-1^{\mathrm{T}}$.

$16 S$ rRNA sequence analysis. PCR amplification of the $16 \mathrm{~S}$ rRNA genes between nucleotides 28 and 1524 allowed us to determine 1,508 nucleotide positions or approximately $98 \%$ of the complete gene (estimated by comparison with the $16 \mathrm{~S}$ rRNA gene of $E$. coli). Masked sequence comparisons of the $16 \mathrm{~S}$ ribosomal DNA of strain PRD- $1^{\mathrm{T}}$ with reference sequence data $(25,38)$ demonstrated that PRD $-1^{\mathrm{T}}$ clusters with the gram-positive bacteria and is most similar to the species having high $\mathrm{G}+\mathrm{C}$ contents, which is consistent with the results of gram staining and with the $\mathrm{G}+\mathrm{C}$ content of the DNA (67.6 mol\%). However, PRD- $1^{\mathrm{T}}$ was not particularly closely related to any of the previously described reference organisms for which sequence data were available. The levels of sequence similarity ranged from 75 to $80 \%$ with the most closely related high-G+C-content gram-positive species. On the basis of fatty acid results, Tindall suspected that strain PRD $-1^{\mathrm{T}}$ was closely related to $R$. radiotolerans (36a). Therefore, the $16 \mathrm{~S}$ rRNA gene sequence of $R$. radiotolerans was determined to compare it with the strain PRD $-1^{\mathrm{T}}$ sequence. Our results showed that the level of sequence similarity between the two organisms was about $90 \%$. Figure 4 shows that strain PRD $-1^{\mathrm{T}}$ and $R$. radiotolerans form a very deeply branching line of descent within the high-G $+\mathrm{C}$-content gram-positive bacteria.

The level of $16 \mathrm{~S}$ rRNA gene sequence similarity between strain PRD $-1^{\mathrm{T}}$ and $R$. radiotolerans $(90 \%)$ is relatively low for species belonging to the same genus (3). However, we decided to place strain PRD-1 ${ }^{\mathbf{T}}$ in the genus Rubrobacter at this time because of the lack of differentiating phenotypic and chemotaxonomic characteristics that would justify creation of another genus, and we propose the name Rubrobacter xylanophilus for this organism.

Description of Rubrobacter xylanophilus. Rubrobacter xylanophilus (xy. la. no' phi. lus. Gr. n. xylon, wood; M. L. n. xylanum, xylan; Gr. adj. philos, liking, friendly to; M. L. adj. xylanophilus, liking xylan). $R$. xylanophilus forms pleomorphic short rodshaped cells that are 0.9 to $1.0 \mu \mathrm{m}$ wide and 1.0 to $3.0 \mu \mathrm{m}$ long; coccoid cells are also present. Gram positive. Colonies on Thermus medium incubated at $60^{\circ} \mathrm{C}$ for 7 days are 1.5 to $2.0 \mathrm{~mm}$ in diameter, circular, convex, smooth, opaque, and light pink. Motility and endospores are not observed. Strain PRD $-1^{\mathrm{T}}$ is aerobic, and no growth occurs under anaerobic conditions. Growth occurs in basal salts medium containing $\left(\mathrm{NH}_{4}\right)_{2} \mathrm{SO}_{4}$ and an appropriate carbon source. The optimum temperature for growth is about $60^{\circ} \mathrm{C}$; no growth occurs at temperatures below $40^{\circ} \mathrm{C}$ or above $70^{\circ} \mathrm{C}$. The optimum $\mathrm{pH}$ for growth is 7.5 to 8.0 ; growth does not occur at $\mathrm{pH}$ values below 6.0 or above 10.0. Cytochrome oxidase, catalase, and $\beta$-galactosidase are present. Xylan is hydrolyzed. Non-fermentative. Nitrate is reduced to nitrite. Growth occurs in Thermus medium containing $6.0 \% \mathrm{NaCl}$. Gelatin, hide powder azure, arbutin, esculin, and hippurate are hydrolyzed. Growth occurs on many common sugars, organic acids, and amino acids. The major respiratory
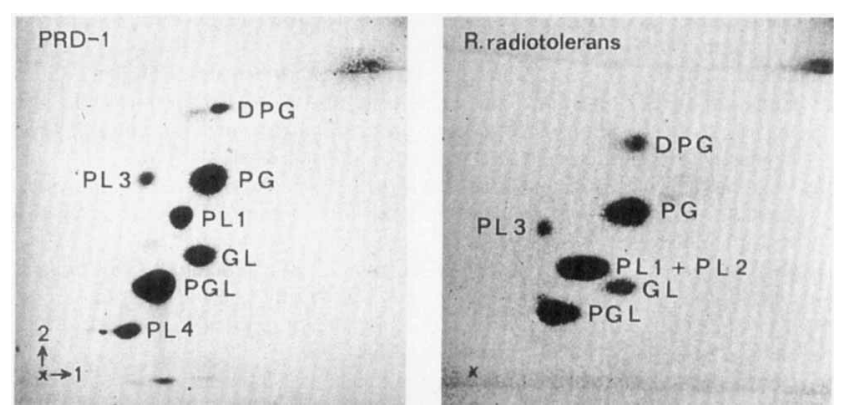

FIG. 3. Two-dimensional thin-layer chromatography of polar lipids of $R$. radiotolerans and strain PRD- $1^{\mathrm{T}}$. Components were revealed by staining the preparations with $5 \%$ molybdophosphoric acid in ethanol and heating them at $160^{\circ} \mathrm{C}$. Abbreviations: PL, phospholipid; PGL, phosphoglycolipid; GL, glycolipid; PG, phosphatidylglycerol; DPG, diphosphatidylglycerol. 

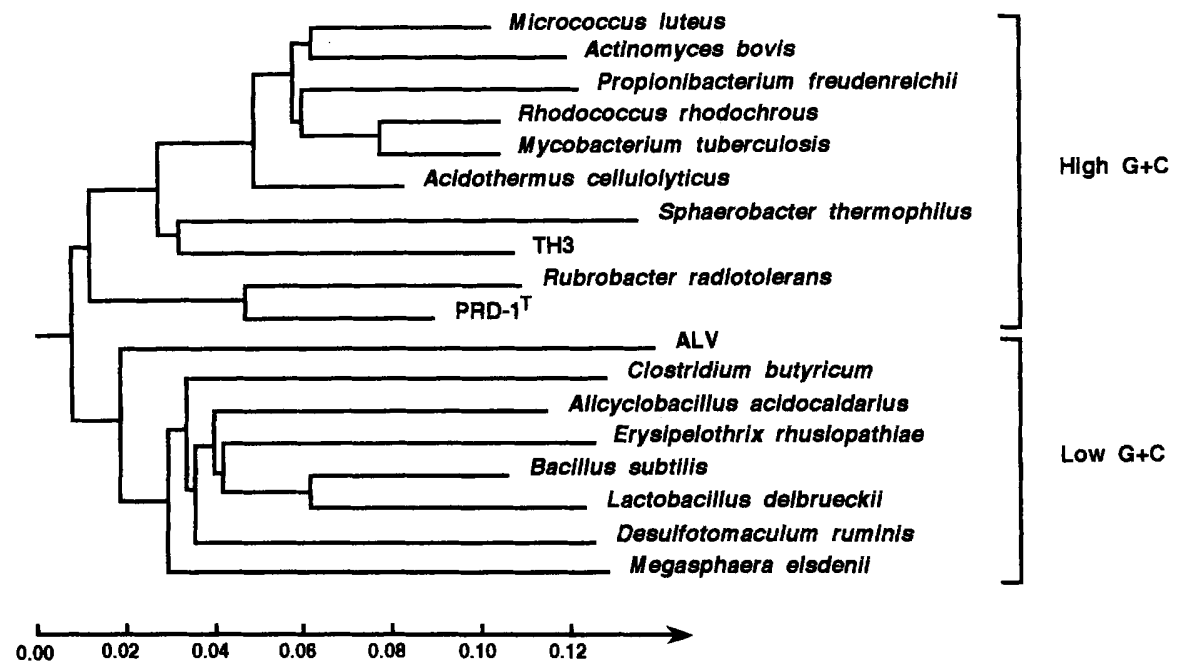

FIG. 4. Rooted dendrogram (based on pairwise 16S rRNA gene sequence comparisons) showing the derived phylogenetic relationships of strain PRD-1 ${ }^{\mathrm{T}}, R$. radiotolerans, and reference strains of the gram-positive phylum. Reference sequence data were obtained from the European Molecular Biology Laboratory (11, 23) and Ribosomal Database Project (25) databases. The scale bar indicates the average number of substitutions per nucleotide position. The root organism was $E$. coli.

quinone is menaquinone 8 , and the major fatty acid is 14 methyl-18:0. The peptidoglycan type is type $\mathrm{A} 3 \alpha$. The $\mathrm{G}+\mathrm{C}$ content of the DNA is $67.6 \mathrm{~mol} \%$. The natural habitat of $R$. xylanophilus is not known.

Type strain PRD-1 has been deposited in the Deutsche Sammlung von Mikroorganismen und Zellkulturen as strain DSM 9941.

\section{ACKNOWLEDGMENTS}

This work was supported by the Commission of European Communities (CEC) Biotech Program (Biotechnology of Extremophiles) Contract BIO2-CT93-0274, by Junta Nacional de Investigação Científica e Tecnológica grant JNICT STRA/BIO/367/92, and by Praxis XXI Program grant Praxis 2/2.1/BIO/20/94 (Portugal). L. Carreto was also supported by Praxis XXI Program grant Praxis XXI/BM/161/94, and E. Moore was supported in part by CEC contract BIO2-CT94-3098.

We are indebted to B. Tindall (Deutsche Sammlung von Mikroorganismen und Zellkulturen, Braunschweig, Germany) for many helpful suggestions, to $\mathrm{H}$. Trüper (University of Bonn, Bonn, Germany) for his advice concerning the name of the organism, and to N. Weiss (Deutsche Sammlung von Mikroorganismen und Zellkulturen, Braunschweig, Germany) for performing the cell wall analysis.

\section{REFERENCES}

1. Brennan, P. J. 1988. Mycobacterium and other actinomycetes, p. 203-298. In C. Ratledge and S. G. Wilkinson (ed.), Microbial lipids, vol. 1. Academic Press, London.

2. Castenholz, R. W. 1969. Thermophilic blue-green algae and the thermal environment. Bacteriol. Rev. 33:476-504.

3. Collins, M. D., P. A. Lawson, A. Willems, J. J. Cordoba, J. FernandezGarayzabal, P. Garcia, J. Cai, H. Hippe, and J. A. E. Farrow. 1994. The phylogeny of the genus Clostridium: proposal of five new genera and eleven new species combinations. Int. J. Syst. Bacteriol. 44:812-826.

4. Degryse, E., N. Glansdorff, and A. Piérard. 1978. A comparative analysis of extreme thermophilic bacteria belonging to the genus Thermus. Arch. Microbiol. 177:189-196.

5. Demharter, W., R. Hensel, J. Smida, and E. Stackebrandt. 1989. Sphaerobacter thermophilus gen. nov., sp. nov. A deeply rooting member of the actinomycetes subdivision isolated from thermophilically treated sewage sludge. Syst. Appl. Microbiol. 11:261-266.

6. Deutsche Sammlung von Mikroorganismen und Zellkulturen. 1993. DSM catalogue of strains. Deutsche Sammlung von Mikroorganismen und Zellkulturen, Braunschweig, Germany.

7. Donato, M. M., E. A. Seleiro, and M. S. da Costa. 1990. Polar lipid and fatty acid composition of strains of the genus Thermus. Syst. Appl. Microbiol. 13. 234-239.

8. Egge, H. 1983. Mass spectrometry of ether lipids, p. 17-47. In H. K. Mangold and F. Paltauf (ed.), Ether lipids: biochemical and biomedical aspects. Academic Press, Inc., New York.

9. Gillis, M., J. De Ley, and M. de Cleene. 1970. The determination of molecular weight of bacterial genome DNA from renaturation rates. Eur. J. Biochem. 12:143-153

10. Gutell, R. R., B. Weiser, C. R. Woese, and H. F. Noller. 1985. Comparative anatomy of 16S-like ribosomal RNA. Prog. Nucleic Acid Res. Mol. Biol. 32: $155-216$.

11. Hamm, G. H., and G. N. Cameron. 1986. The EMBL data library. Nucleic Acids Res. 14:5-9.

12. Harvey, D. J. 1982. Picolinyl esters as derivatives for the structural determination of long chain branched and unsaturated fatty acids. Biomed. Mass Spectrom. 9:33-38.

13. Jukes, T. H., and C. R. Cantor. 1969. Evolution of protein molecules, p. 21-132. In H. N. Munro (ed.), Mammalian protein metabolism. Academic Press, Inc., New York.

14. Karison, U., D. F. Dwyer, S. W. Hooper, E. R. B. Moore, K. N. Timmis, and L. D. Eltis. 1993. Two independently regulated cytochromes $p-450$ in a Rhodococcus rhodochrous strain that degrades 2-ethoxyphenol and 4-methoxybenzoate. J. Bacteriol. 175:1467-1474.

15. Kroppenstedt, R. M. 1985. Fatty acid and menaquinone analysis of actinomycetes and related organisms, p. 173-200. In M. Goodfellow and D. E. Minnikin (ed.), Chemical methods in bacterial systematics. Academic Press, Inc., London.

16. Kuykendall, L. D., M. A. Roy, J. J. O'Neill, and T. E. Devine. 1988. Fatty acids, antibiotic resistance, and deoxyribonucleic acid homology groups of Bradyrhizobium japonicum. Int. J. Syst. Bacteriol. 38:358-361.

17. Lane, D. J. 1991. 16S/23S sequencing, p. 115-175. In E. Stackebrandt and M. Goodfellow (ed.), Nucleic acid techniques in bacterial systematics. John Wiley \& Sons, Chichester, United Kingdom.

18. Lee, Y.-E., M. K. Jain, C. Lee, S. E. Lowe, and J. G. Zeikus. 1993. Taxonomic distinction of saccharolytic thermophilic anaerobes: description of Thermoanaerobacterium xylanolyticum gen. nov., sp. nov., and Thermoanaerobacterium saccharolyticum gen. nov., sp. nov.; reclassification of Thermoanaerobium brockii, Clostridium thermosulfurogenes, and Clostridium thermohydrosulfuricum E100-69 as Thermoanaerobacter brockii comb. nov., Thermoanaerobacterium thermosulfurigenes comb. nov., and Thermoanaerobacter thermohydrosulfuricus comb. nov., respectively; and transfer of Clostridium thermohydrosulfuricum $39 \mathrm{E}$ to Thermoanaerobacter ethanolicus. Int. J. Syst. Bacteriol. 43:4151.

19. Manaia, C. M., and M. S. da Costa. 1991. Characterization of halotolerant Thermus isolates from shallow marine hot springs on S. Miguel, Azores. J. Gen. Microbiol. 137:2643-2648.

20. Marmur, J., and P. Doty. 1962. Determination of the base composition of deoxyribonucleic acid from its thermal denaturation temperature. J. Mol. Biol. 5:109-118.

21. Minnikin, D. E., I. G. Hutchinson, and A. B. Caldicott. 1980. Thin-layer chromatography of methanolysates of mycolic acid-containing bacteria. J. Chromatogr. 188:221-233.

22. Mullis, K. B., and F. Faloona. 1987. Specific synthesis of DNA in vitro via a polymerase-catalysed chain reaction. Methods Enzymol. 155:335-350. 
23. Neess, J. M., Y. Van de Peer, P. De Rijk, S. Chapelle, and R. De Wachter. 1993. Compilation of small ribosomal subunit RNA structures. Nucleic Acids Res. 21:3025-3049.

24. Olsen, G. J. 1987. The earliest phylogenetic branchings: comparing rRNAbased evolutionary trees inferred with various techniques. Cold Spring Harbor Symp. Quant. Biol. 52:825-838.

25. Olsen, G. J., N. Larsen, and C. R. Woese. 1991. The Ribosomal Database Project. Nucleic Acids Res. 19:2017-2021.

26. Pond, J. L., T. A. Langworthy, and G. Holzer. 1986. Long-chain diols: a new class of membrane lipids from a thermophilic bacterium. Science 231:1134 1136 .

27. Prado, A., M. S. da Costa, and V. M. C. Madeira. 1988. Effect of growth temperature on the lipid composition of two strains of Thermus sp. J. Gen. Microbiol. 134:1653-1660.

28. Rainey, F. A., and E. Stackebrandt. 1993. Transfer of the type species of the genus Thermobacteroides to the genus Thermoanaerobacter as Thermoanaerobacter acetoethylicus (Ben-Bassat and Zeikus 1981) comb. nov., description of Coprothermobacter gen. nov., and reclassification of Thermobacteroides proteolyticus as Coprothermobacter proteolyticus (Ollivier et al, 1985) comb. nov. Int. J. Syst. Bacteriol. 43:857-859.

29. Ryhage, R., and E. Stenhagen. 1960. Mass spectrometry in lipid research. J. Lipid Res. 1:361-390.

30. Saiki, R. K., D. H. Gelfand, S. Stoffel, S. J. Scharf, R. Higuchi, G. T. Horn, K. B. Mullis, and H. A. Ehrlich. 1988. Primer-directed enzymatic amplification of DNA with a thermo-stable DNA polymerase. Science 239:487-491.

31. Santos, M. A., R. A. D. Williams, and M. S. da Costa. 1989. Numerical taxonomy of Thermus isolates from hot springs in Portugal. Syst. Appl. Microbiol. 12:310-315.

32. Schleifer, K.-H., and O. Kandler. 1972. Peptydoglycan types of bacterial cell walls and their taxonomic implications. Bacteriol. Rev. 36:407-477.

33. Sharp, R. J., P. W. Riley, and D. White. 1992. Heterotrophic thermophilic bacilli, p. 19-50. In J. K. Kristjansson (ed.), Thermophilic bacteria. CRC Press, Inc., London.

34. Stackebrandt, E., R. M. Kroppenstedt, K.-D. Jahnke, C. Kemmerling, and H. Gürtler. 1994. Transfer of Streptosporangium viridogriseum (Okuda et al. 1966), Streptosporangium viridogriseum subsp. kofuense (Nonomura and
Ohara 1969), and Streptosporangium albidum (Furamai et al. 1968) to Kutzneria gen. nov. as Kutzneria viridogrisea comb. nov., Kutzneria kofuensis comb. nov., and Kutzneria albida comb. nov., respectively, and emendation of the genus Streptosporangium. Int. J. Syst. Bacteriol. 44:265-269.

35. Suzuki, K., M. D. Collins, E. Ijjima, and K. Komagata. 1988. Chemotaxonomic characterization of a radiotolerant bacterium, Arthrobacter radiotolerans: description of Rubrobacter radiotolerans gen. nov., comb. nov. FEMS Microbiol. Lett. 52:33-40.

36. Tindall, B. J. 1989. Fully saturated menaquinones in the archaebacterium Pyrobaculum islandicum. FEMS Microbiol. Lett. 60:251-254.

36a.Tindall, B. J. Personal communication.

37. Vainshtein, M., H. Hippe, and R. M. Kroppenstedt. 1992. Cellular fatty acid composition of Desulfovibrio species and its use in classification of sulfatereducing bacteria. Syst. Appl. Microbiol. 15:554-566.

38. Van de Peer, Y., I. Van den Broeck, P. de Rijk, and R. de Watcher. 1994. Database on the structure of small ribosomal subunit RNA. Nucleic Acids Res. 22:3488-3494.

39. Wait, R., and M. J. Hudson. 1985. The use of picolinyl esters for the characterization of microbial lipids; application to Campylobacter species. Lett. Appl. Microbiol. 1:95-99.

40. Wiegel, J. 1992. The anaerobic thermophilic bacteria, p. 105-184. In J. K. Kristjansson (ed.), Thermophilic bacteria. CRC Press, Inc., London.

41. Williams, R. A. D., and M. S. da Costa. 1992. The genus Thermus and related microorganisms, p. 3745-3753. In A. Balows, H. G. Trüper, M. Dworkin, W. Harder, and K. H. Schleifer (ed.), The prokaryotes, 2nd ed. Springer-Verlag, New York.

42. Wilson, K. 1987. Preparation of genomic DNA from bacteria, p. 241-242. In F. M. Ausubel, R. Brent, R. E. Kingston, D. D. Moore, J. G. Seidman, J. A. Smith, and K. Struhl (ed.), Current protocols in molecular biology. John Wiley \& Sons, Inc., New York.

43. Woese, C. R., R. Gutell, R. Gupta, and H. F. Noller. 1983. Detailed analysis of the higher-order structure of $16 \mathrm{~S}$-like ribosomal ribonucleic acids. Microbiol. Rev. 47:621-669.

44. Yoshinaka, T., K. Yano, and H. Yamaguchi. 1973. Isolation of a highly radioresistant bacterium, Arthrobacter radiotolerans nov. sp. Agric. Biol. Chem. 37:2269-2275. 